\title{
Test usposobljenosti Laboratorija za varstvo gozdov za detekcijo glive Gibberella circinata - poročilo
}

\section{Barbara PIŠKUR*}

Gliva Gibberella circinata Nirenberg \& O’Donnell (anamorf Fusarium circinatum Nirenberg \& O’Donnell) povzroča bolezen borov, ki jo imenujemo borov smolasti rak. Pojavi se lahko pri vseh starostnih obdobjih drevesa in na vseh delih drevesa - tako reproduktivnih kot vegetativnih. Bolezen prepoznamo po rakastih razjedah, za katere nastanek kalusa ni karakterističen. Značilno je obilno izločanje smole, po katerem je bolezen tudi dobila ime. Smola se nalaga tudi v notranjosti drevesa, kar povzroči značilno jantarno obarvanost lesa. Močnejše okužbe se odrazijo v močno prizadetih krošnjah, drevo sčasoma odmre. Okužba z borovim smolastim rakom zmanjšuje odpornost drevesa in $s$ tem povečuje verjetnost okužb $\mathrm{z}$ drugimi škodljivimi organizmi. Gliva kuži tudi duglazije, vendar so okužbe običajno brez vidnih znakov. Bolezen je razširjena v Španiji na obsežnem območju, posamične najdbe pa so bile v Franciji, Italiji in na Portugalskem (povzeto po EPPO, 2009; EFSA, 2010).

Gliva G. circinata je uvrščena v Prilogo II.A1 Direktive Sveta št. 2000/29/ES. Z Odločbo komisije o začasnih nujnih ukrepih za preprečevanje vnosa glive Gibberella circinata v Skupnost in njenega širjenja v Skupnosti (2007/433/ES) je Evropska skupnost uvedla obvezen nadzor nad pojavom in širjenjem omenjenega organizma. V Sloveniji poteka nadzor za glivo G. circinata od leta 2008. Gliva do sedaj v Sloveniji še ni bila dokazana. V kolikor bi v Sloveniji potrdili prisotnost glive $G$. circinata, bi pričeli z izvajanjem ukrepov za zatiranje ali/in preprečevanje širjenja škodljivega organizma. $\mathrm{Z}$ zakonodajo predpisani ukrepi so rigorozni in bodo obsegali obsežno uničenje gostiteljskih dreves ter bodo vplivali na strukturo gozda v okolici najdbe. Zato so za izvajanje nadzora in preprečevanje širjenja bolezni ključne zanesljive in verodostojne diagnostične metode.

Laboratorij za varstvo gozdov (LVG) je s strani Uprave RS za varno hrano, veterinarstvo in varstvo rastlin (UVHVVR) pooblaščen laboratorij za diagnostiko glive $G$. circinata v gozdnem reprodukcijskem materialu (semena borov in duglazij). Z letom 2014 laboratorij izvaja tudi uradno diagnostiko rastlinskega materiala $s$ sumom na borov smolasti rak. Diagnostične metode za ugotavljanje okužb z glivo G. circinata so opisane v internih standardnih operativnih postopkih LVG, ki se navezujejo na priporočila Evropske in mediteranske organizacije za varstvo rastlin (EPPO 2009). LVG ima za zagotavljanje zanesljivosti in ponovljivosti analiz vpeljan sistem kakovosti, ki je določen z internim Poslovnikom kakovosti LVG in sledi določilom standarda ISO/IEC 17025. Pomemben pokazatelj usposobljenosti in kakovosti laboratorija za izvedbo diagnostičnih analiz so tudi testi usposobljenosti (ang. proficiency test) (EPPO, 2014).

Decembra 2013 je LVG sodeloval v testu usposobljenosti, ki ga je organiziral Anses-Laboratorie de la santé des végétaux, Francija, in sicer za diagnostiko $G$. circinata $\mathrm{v}$ semenih borov. Prejeli smo 15 vzorcev zmletih semen iz rodu Pinus, ki so bila predhodno inkubirana v obogatitvenem tekočem gojišču. Preizkusili smo diagnostično metodo, ki vključuje molekularne analize, in sicer PCR z vrstno specifičnimi začetnimi oligonukleotidi ter potrditev dobljenega produkta PCR s sekvenciranjem. Omenjeno metodo v LVG največkrat uporabljamo za testiranje semen borov za namen izdaje rastlinskih potnih listov.

Rezultati medlaboratorijskega testa so pokazali, da sta tako izvedba kot protokol našega dela ustrezni (preglednica 1 in 2). Sodelovanje v omenjenem testu je bil izziv in je pokazatelj kakovosti našega izvajanja analiz za detekcijo G. circinata.

Preglednica 1: Zaključki analize ustreznosti rezultatov za Laboratorij za varstvo gozdov (izračuni ANSES)

\begin{tabular}{|l|l|l|}
\hline Kriterij & Pričakovan rezultat & Rezultat \\
\hline OBČUTLJIVOST & $100 \%$ & $100 \%$ \\
\hline SPECIFIČNOST & $100 \%$ & $100 \%$ \\
\hline PONOVLJIVOST & $100 \%$ & $100 \%$ \\
\hline PRAVILNOST & $100 \%$ & $100 \%$ \\
\hline
\end{tabular}

\section{Viri}

EPPO, 2009. PM 7/91 (1): Gibberella circinata. EPPO Bullettin, 39: 298-309

EFSA, 2010. Risk assessment of Gibberella circinata for the EU territory and identification and evaluation of risk management options. EFSA Journal, 8: 1-93

EPPO, 2014. PM 7/98 (2): Specific requirements for laboratories preparing accreditation for a plant pest diagnostic activity. EPPO Bulletin (v tisku)

Gozdarski inštitut Slovenije, Oddelek za varstvo gozdov, Večna pot 2, 1000 Ljubljana

*barbara.piskur@gozdis.si

Preglednica 2: Rezultati diagnostičnega postopka za ugotavljanje okužb vzorcev z glivo G. circinata v okviru testa usposobljenosti za Laboratorij za varstvo gozdov (oznaka v testu »Lab02«)

\begin{tabular}{|l|c|c|c|c|c|c|c|c|c|c|c|c|c|c|c|c|c|c|} 
Vzorec & $\mathbf{2}$ & $\mathbf{2}$ & $\mathbf{3}$ & $\mathbf{4}$ & $\mathbf{5}$ & $\mathbf{6}$ & $\mathbf{7}$ & $\mathbf{8}$ & $\mathbf{9}$ & $\mathbf{1 0}$ & $\mathbf{1 1}$ & $\mathbf{1 2}$ & $\mathbf{1 3}$ & $\mathbf{1 4}$ & 15 \\
\hline Pričakovan rezultat & + & - & - & + & + & + & + & + & + & + & - & - & - & - & + \\
\hline Lab02 & + & - & - & + & + & + & + & + & + & + & - & - & - & - & + \\
\hline
\end{tabular}

